\title{
PENERAPAN MODEL PROJECT BASED LEARNING UNTUK MENINGKATKAN LITERASI SAINS MAHASISWA PENDIDIKAN IPA
}

\author{
${\text { Indra Sakti*1, }{ }^{1} \text { Nirwana }}^{2}$, Eko Swistoro ${ }^{3}$ \\ 1,2 Program Studi Pendidikan IPA FKIP Universitas Bengkulu \\ ${ }^{3}$ Program Studi Pendidikan Fisika FKIP Universitas Bengkulu \\ Jl. WR. Supratman, Kandang Limun, Bengkulu \\ Email : isyakti@unib.ac.id
}

\begin{tabular}{|l|c|c|c} 
Diterima 24 Februari 2021 & Direvisi 31 Maret 2021 & Disetujui 20 April 2021 & Dipublikasikan 30 April 2021
\end{tabular}

https://doi.org/10.33369/jkf.4.1.35-42

\begin{abstract}
ABSTRAK
Dilakukan penelitian tindakan kelas (Classroom Action Research) dengan penerapan model Project Based Learning (PjBL) di Program Studi Pendidikan IPA FKIP Universitas Bengkulu Tahun 2020 pada mata kuliah IPA-3. Penelitian ini secara umum bertujuan meningkatkan literasi sains mahasiswa calon guru IPA. Sedangkan tujuan khusus adalah untuk (1) menghasilkan perangkat pembelajaran dengan Project Based Learning (PjBL) berupa rencana pelaksanaan pembelajaran (RPP) dan lembar kegiatan peserta didik (LKPD) yang dilengkapi instrumen tes literasi sains (2) mendeskripsikan peningkatan literasi sains mahasiswa dengan Pembelajaran Berbasis Proyek (3) mendeskripsikan peningkatan aktivitas belajar mahasiswa dengan Pembelajaran Berbasis Proyek. Penelitian ini merupakan penelitian Classroom Action Research (penelitian tindakan kelas/PTK) dengan 4 siklus yaitu perencanaan (planning), Tindakan (Acting), observasi (observation), dan refleksi (reflection). Pada tahap perencanaan (planning), dilakukan beberapa kegiatan sebagai perancangan produk awal, yaitu: (1) pengembangan perangkat pembelajaran yaitu (a) RPP (b) bahan ajar (c) LKPD (d) Instrumen tes Literasi Sains. (2) Validasi ahli (content validity) perangkat pembelajaran. Hasil penelitian menunjukkan bahwa perangkat pembelajaran valid. (a) aktivitas mahasiswa menunjukkan peningkatan yakni dari 3,62 pada siklus I menjadi 3,74 pada siklus II. (b) Literasi sains mahasiswa menunjukkan bahwa rata-rata persentase kemampuan literasi sains mahasiswa baik pada 3 aspek literasi sains yaitu aspek konten $(53,80 \%)$, aspek proses $(44,038 \%)$ dan aspek konteks $(35,088 \%)$.
\end{abstract}

Kata Kunci : Model Project Based Learning, Literasi Sains

\begin{abstract}
Classroom Action Research was carried out by applying the Project Based Learning (PjBL) model in the Science Education Study Program FKIP Bengkulu University in 2020 in the IPA-3 course. This research generally aimed to improve the science literacy of science teacher student candidates. While the specific objectives were (1) to produce learning tools with Project Based Learning (PjBL) in the form of a learning implementation plan (RPP) and student activity sheets (LKPD) equipped with scientific literacy test instruments (2) to describe the increase in student scientific literacy with Project Based Learning (PjBL). (3) describes an increase in student learning activities with Project Based Learning (PjBL). This research was a Classroom Action Research (classroom action research / CAR) with 4 cycles, namely planning (planning), action (acting), observation (observation), and reflection (reflection). At the planning stage, several activities were carried out as the initial product design, namely: (1) developing learning tools, namely (a) RPP (b) teaching materials (c) LKPD (d) Scientific Literacy test instruments. (2) Expert validation (content validity) of learning tools. The results showed that the learning device was valid. Student activity showed an increase, from 3.62 in the first cycle to 3.74 in the second cycle. Student science literacy showed that the average percentage of students' scientific literacy skills was good in 3 aspects of scientific literacy, namely the content aspect $(53.80 \%)$, the process aspect $(44.038 \%)$ and the context aspect $(35.088 \%)$.
\end{abstract}

Keywords : Project Based Learning, Science Literacy

\section{PENDAHULUAN}

Menurut National Research Council (1996) rendahnya kontribusi pembelajaran sains terhadap keberhasilan peserta didik/mahasiswa disebabkan karena terlepasnya pembejaran sains dari (c) 2021 Jurnal Kumparan Fisika 
konteks sosial, hanya menitikberatkan pada penguasaan materi, dan penggunaan asesmen yang tidak tepat sehingga mahasiswa hanya menguasai pengetahuan. Dalam pembelajaran seharusnya mahasiswa mengetahui relevansi pembelajaran sains terhadap kehidupan sehari-hari dan kehidupan bermasyarakat. Hoolbrook menyatakan pembelajaran sains sebaiknya diarahkan pada pemahaman betapa pentingnya sains bila dikaitkan dengan masyarakat di masa lalu, kini atau masa datang (1).

Ada banyak pembekalan yang bisa diberikan kepada mahasiswa untuk mengimbangi perkembangan teknologi, salah satunya literasi sains. Literasi sains merupakan aspek penting yang bisa dijadikan bekal bagi mahasiswa untuk menghadapi perkembangan teknologi yang semakin canggih, terutama dalam hal mengakses informasi. Bond mengemukakan bahwa peserta didik yang memiliki pengetahuan untuk memahami fakta ilmiah serta hubungan antara sains, teknologi dan masyarakat, dan mampu menerapkan pengetahuannya untuk memecahkan masalah-masalah dalam kehidupan nyata disebut dengan masyarakat berliterasi sains. Literasi sains merupakan salah satu keterampilan yang diperlukan di abad 21 diantara 16 keterampilan yang diidentifikasi oleh World Economic Forum. Menurut DeBoer, mengingat pentingnya literasi sains maka mendidik masyarakat agar memiliki literasi sains merupakan tujuan utama dalam setiap reformasi pendidikan sains (2).

Berdasarkan Kerangka Asesmen Literasi Sains PISA 2015 terdapat beberapa aspek dalam penilaian PISA 2015, yaitu (a) Pengetahuan ilmiah atau konten (b) Proses; (c) Konteks (3). Literasi sains bersifat multi dimensional dalam pengukurannya, yaitu meliputi konten sains, proses sains dan konteks sains. Konten sains merujuk pada konsep kunci sains yang diperlukan untuk memahami fenomena alam dan perubahannya yang terjadi akibat kegiatan manusia. Proses sains mengkaji kemampuan untuk menggunakan pengetahuan dan pemahaman ilmiah. Dalam penilaian literasi sains tiga aspek proses sains yang ditetapkan mengacu pada PISA (Program for International Student Assessment) yaitu mengidentifikasi pertanyaan ilmiah, menjelaskan fenomena secara ilmiah, dan menggunakan bukti ilmiah. Konteks literasi sains mencakup bidang-bidang aplikasi sains dalam kehidupan personal, sosial, dan global yang meliputi kesehatan, sumber daya alam, mutu lingkungan, bahaya, dan pekembangan mutakhir sains dan teknologi (4).

Literasi sains penting bagi mahasiswa untuk memahami lingkungan, kesehatan, ekonomi, sosial modern, dan teknologi. Kemajuan teknologi memiliki dampak pada perilaku dan kebiasaan seseorang, terutama dalam cara mengakses dan mendapatkan informasi. Kemudahan mengakses informasi di era teknologi yang semakin canggih harus diimbangi dengan pembekalan berupa pengetahuan, sikap dan keterampilan generasi industri 4.0.

Literasi sains dapat diartikan sebagai melek sains, baik melek sains dalam hal konsep maupun melek sains dalam aplikasinya. Pengertian yang lebih luas dan mendalam, literasi sains terdiri dari empat domain yaitu domains konteks, kompetensi sains, pengetahuan sains, dan sikap terhadap sains. Empat domain literasi sains inilah yang harus dimiliki mahasiswa generasi zaman industri 4.0 sebagai bekal dalam menghadapi perkembangan teknologi yang semakin pesat. Dengan menguasai domain konteks ini mahasiswa diharapkan bisa mengetahui, memilih dan memilah jenis informasi yang disesuaikan dengan lingkup dan bidangnya. Selain itu mahasiswa dapat mengkaji informasi mengenai isu-isu konstekstual dan menerapkannya dalam kehidupan sehari-hari untuk mengatasi permasalahan pribadi dan masyarakat umum. Mahasiswa perlu memiliki kompetensikompetensi tersebut supaya informasi yang diakses dan diperoleh dapat dikaji dan di uji kebenarannya secara ilmiah sehingga tidak akan ada informasi yang bersifat hoax dan tidak benar. Selain itu, kompetensi-kompetensi tersebut juga akan membantu mahasiswa membaca dan memahami data dalam berbagai bentuk sehingga mampu menarik kesimpulan valid dari data yang tersebar pada berbagai sumber (5).

Keterampilan literasi sains sejalan dengan pendidikan pada era revolusi industri 4.0 diarahkan untuk pengembangan kompetensi abad ke-21, yang terdiri dari tiga komponen utama yaitu kompetensi berpikir, bertindak, dan hidup di dunia. Komponen berpikir meliputi berpikir kritis,berpikir kreatif, dan kemampuan pemecahan masalah. Komponen bertindak meliputi komunikasi, kolaborasi, literasi data, literasi teknologi, dan literasi manusia. Komponen hidup di masyarakat meliputi inisiatif, mengarahkan diri (self-direction), pemahaman global, serta tanggung jawab sosial (6). 
Keterampilan literasi sains bukanlah keterampilan yang dibawa oleh seseorang sejak lahir, sehingga keterampilan ini dapat dilatihkan dan dikembangkan melalui proses pembelajaran. Dalam proses pembelajaran, dosen berperan sebagai mediator dan fasilitator. Sehingga dalam pelaksanaannya, dosen dapat mendesain dan menerapkan model pembelajaran untuk meningkatkan keterampilan literasi sains mahasiswa.

Mata kuliah IPA-3 adalah salah satu mata kuliah wajib bagi mahasiswa S1 Pendidikan IPA. Mata kuliah ini dirancang untuk meningkatkan pemahaman mahasiswa pada materi IPA SMP kelas IX dan mampu menerapkannya dalam pembelajaran IPA kelas IX. Capaian pembelajaran mata kuliah IPA 3 adalah: (1) mampu mengeksplorasi hakekat sains pada buku IPA kelas IX, (2) mampu menganalisis materi dari buku IPA kelas IX (3) mampu mengidentifikasi dan menganalisis PjBL pada buku IPA kelas IX. (4) Mampu mengaplikasikan pembelajaran PjBL dalam tataran yang konkrit.

Hasil observasi yang dilakukan pada mahasiswa semester V tahun ajaran 2020/2021 ketika belajar pada mata kuliah IPA-3 diketahui bahwa: (1) Proses perkuliahan yang dilakukan oleh dosen menerapkan metode tugas kelompok, presentasi dan diskusi. Pembelajaran dimulai dari kelompok penyaji presentasi, kemudian didiskusikan secara klasikal oleh mahasiswa, dengan kata lain dosen berfungsi sebagai fasilitator. Dosen sudah memvariasikan model pembelajaran, namun belum terlihat pembelajaran yang aktif. (2) Aktivitas belajar mahasiswa kurang aktif dalam pembelajaran. (3) Kegiatan pembelajaran berlangsung tidak begitu menarik karena penekanan pembelajaran selalu pada penguasaan konsep bukan pada proses. (4) Kemampuan komunikasi mahasiswa baik lisan maupun tulisan masih sangat terbatas. (5) mahasiswa belum mampu mendefinisikan konsep; (6) literasi sains mahasiswa masih rendah.

Mahasiswa Program Studi Pendidikan IPA dihadapkan kepada dua tuntutan sekaligus yakni sebagai individu anggota masyarakat di era industri 4.0 dengan literasi baru dan calon guru IPA. Mengacu pada era industri 4.0 dengan literasi baru, yang ditandai perkembangan pendidikan dan kemajuan teknologi dan informasi yang sangat pesat. Hal ini ditunjukkan dengan banyaknya penerapan teknologi canggih berupa aplikasi yang menyediakan kebutuhan untuk mempermudah kelangsungan hidup manusia. Di era industri 4.0 dengan literasi baru ini pendidikan menjadi semakin penting untuk menjamin mahasiswa memiliki keterampilan dan berinovasi, keterampilan menggunakan teknologi dan media informasi, serta dapat bekerja, dan bertahan dengan menggunakan keterampilan untuk hidup (life skills) (2).

Guru-guru IPA juga pada umumnya memiliki tanggung jawab dalam menghadapi permasalahan dengan hasil uji program PISA, dimana hasil literasi sains siswa-siswa sangat rendah dan jauh dibawah rata-rata pencapaian siswa-siswa negara lain. Skor literasi sains siswa bangsa Indonesia yang telah mengikuti program PISA sejak tahun 2000 hingga 2018 tidak mengalami kemajuan. Hasil Programme for International Student Assessment (PISA) untuk Indonesia tahun 2018 adalah rerata skor PISA negara anggota OECD untuk sains 489 dan rerata skor kemampuan sains siswa bangsa Indonesia kembali mengalami penurunan di angka 396. Maka sebagai mahasiswa calon guru IPA seharusnya menerima tantangan ini dengan mempersiapkan diri lebih baik. Salah satu cara mempersiapkan mahasiswa terkait literasi sains adalah meningkatkan literasi sains mahasiswa itu sendiri melalui pembelajaran dengan project based learning.

Pembelajaran berbasis proyek (project based learning) adalah model pembelajaran yang melibatkan peserta didik dalam suatu kegiatan (proyek) yang menghasilkan suatu produk. Tahapan/langkah-langkah pelaksanaan sebagai berikut (a) Penentuan pertanyaan mendasar (Start with the essential question); (b) Mendesain perencanaan proyek yang akan dilakukan (Design a plan for the project); (c) Menyusun jadwal yang akan dilakukan (Create a schedule), guru dan peserta didik secara kolaboratif menyusun jadwal aktivitas dalam menyelesaikan proyek antara lain : (1) membuat timeline menyelesaikan proyek, (2) membuat deadline penyelesaian proyek, (3) peserta didik jika akan merencanakan cara yang baru, (4) membimbing peserta didik melaksanakan proyek yang akan dilakukan dan (5) peserta didik untuk membuat penjelasan pemilihan proyek yang akan dilakukan; (d) Memonitor peserta didik dan kemajuan proyek yang akan dilakukan (Monitor the students and the progress of the project); (e) Menguji hasil (Assess the outcome); (f) 
Mengevaluasi pengalaman (Evaluate the experience) (7). Melalui langkah-langkah tersebut, pembelajaran IPA dengan project based learning diduga dapat meningkatkan literasi sains mahasiswa. Adapun penelitian ini secara umum bertujuan meningkatkan literasi sains mahasiswa calon guru IPA. Sedangkan tujuan khusus adalah untuk (1) menghasilkan perangkat pembelajaran dengan Project Based Learning (PjBL) berupa rencana pelaksanaan pembelajaran (RPP) dan lembar kegiatan peserta didik (LKPD) yang dilengkapi instrumen tes literasi sains (2) mendeskripsikan peningkatan literasi sains mahasiswa dengan Pembelajaran Berbasis Proyek (3) mendeskripsikan peningkatan aktivitas belajar mahasiswa dengan Pembelajaran Berbasis Proyek.

\section{METODOLOGI PENELITIAN}

Penelitian ini merupakan penelitian Classroom Action research (CAR). Model CAR dengan 4 siklus yaitu: perencanaan (planning), tindakan (acting), observasi (observation), dan refleksi (reflection) (8) Penelitian ini dilaksanakan pada mahasiswa Program Studi Pendidikan IPA FKIP Universitas Bengkulu. Pelaksanaan penelitian selama 6 bulan, mulai Juli sampai dengan Desember 2020. Subjek penelitian adalah mahasiswa semester 5 Program Studi Pendidikan IPA FKIP Universitas Bengkulu pada matakuliah IPA-3 Tahun Akademik 2020/2021 yang jumlahnya 26 orang. Pengambilan subjek penelitian ini menggunakan teknik purposive sampling. Purposive sampling adalah suatu teknik pengambilan sampel non-random karena objek dan subjek yang dipilih didasarkan pada pertimbangan tertentu (9). Teknik pengumpulan data adalah teknik tes dan non-tes. Teknik non-tes dilakukan dengan menggunakan daftar check list yaitu dengan memberikan tanda check (v) saat melakukan pengamatan/observasi pada indikator-indikator literasi sains dan teknik tes soal mutiple choice mengadopsi soal PISA. Teknik tes dilakukan dengan memberikan skor pada tes yang dikerjakan oleh mahasiswa. Tes yang diberikan berupa tes tertulis untuk mengukur domain konten dan konteks sains. Analisis data dilakukan dengan analisis deskriptif dan uji validitas perangkat pembelajaran.

\section{HASIL DAN PEMBAHASAN}

Penelitian ini dilakukan dengan metode Penelitian Tindakan Kelas (Classroom Action Research). Implementasi penelitian tindakan kelas dalam pembelajaran ini 2 siklus dengan masingmasing siklus empat langkah yaitu perencanaan, tindakan, observasi dan refleksi. Pelaksanaan pembelajaran diterapkan model Project Based Learning (PjBL). Siklus I Materi Listrik Statis dalam Kehidupan Sehari-hari dan Siklus II Materi Listrik Dinamis dalam Kehidupan Sehari-hari

\subsection{Aktivitas Pembelajaran Dosen}

Penerapan PjBL telah dilaksanakan dua kali pertemuan pada materi Listrik Statis dalam Kehidupan Sehari-hari dan Listrik Dinamis dalam Kehidupan Sehari-hari. Adapun data hasil observasi aktivitas pembelajaran terdapat pada tabel 1 .

Tabel 1. Data Aktivitas Pembelajaran

\begin{tabular}{|c|c|c|}
\hline Langkah PjBL & Siklus I & Siklus II \\
\hline A. Pendahuluan & 4 & 4 \\
\hline \multicolumn{3}{|l|}{ B. Kegiatan Inti (10) } \\
\hline 1. Pertanyaan mendasar (Start with the essential question) & 4 & 4 \\
\hline $\begin{array}{l}\text { 2. Mendesain perencanaan produk (Design a plan for the } \\
\text { project); }\end{array}$ & 3 & 4 \\
\hline 3. Menyusun jadwal pembuatan (Create a schedule), & 4 & 4 \\
\hline $\begin{array}{l}\text { 4. Memonitor kemajuan proyek (Monitor the students and } \\
\text { the progress of the project); }\end{array}$ & 4 & 4 \\
\hline 5. Menguji hasil (Assess the outcome); & 4 & 4 \\
\hline 6. Evaluasi pengalaman (Evaluate the experience). & 4 & 4 \\
\hline C. Penutup & 4 & 4 \\
\hline Jumlah & 31 & 32 \\
\hline Rata-rata & 3,88 & 4 \\
\hline Kategori & SB & SB \\
\hline
\end{tabular}

Penerapan Model Project Based Learning untuk Meningkatkan Literasi Sains Mahasiswa Pendidikan IPA

Indra Sakti, Nirwana, Eko Swistoro 
Aktivitas pembelajaran meningkat dari penilaian 3,88 berkategori sangat baik pada siklus I menjadi 4 dengan kategori sangat baik pada siklus II. Dengan demikian aktivitas dosen sudah dapat mendukung untuk meningkatkan aktivitas dan literasi sains mahasiswa.

\subsection{Data Aktivitas Mahasiwa}

Penilaian terhadap aktivitas belajar mahasiswa diperoleh data sebagai berikut.

Tabel 2. Data Aktivitas Belajar Mahasiswa

\begin{tabular}{|c|c|c|c|}
\hline & Langkah PBL & Siklus I & Siklus II \\
\hline \multicolumn{4}{|c|}{ A. Pendahuluaan } \\
\hline \multicolumn{4}{|c|}{ B. Kegiatan Inti: } \\
\hline & 1. Pertanyaan mendasar (Start with the essential question) & 3,27 & 3,38 \\
\hline & $\begin{array}{l}\text { 2. Mendesain perencanaan proyek yang akan dilakukan } \\
\text { (Design a plan for the project); }\end{array}$ & 3,73 & 3,81 \\
\hline & $\begin{array}{l}\text { 3. Menyusun jadwal yang akan dilakukan (Create a } \\
\text { schedule), }\end{array}$ & 3,85 & 4,00 \\
\hline & $\begin{array}{l}\text { 4. Memonitor mahasiswa dan kemajuan proyek yang } \\
\text { dilakukan (Monitor the students and the progress of the } \\
\text { project); }\end{array}$ & 4,00 & 4,00 \\
\hline & 5. Menguji hasil (Assess the outcome); & 3,58 & 3,77 \\
\hline & 6. Mengevaluasi pengalaman (Evaluate the experience). & 3,23 & 3,50 \\
\hline \multicolumn{4}{|c|}{ Penutup } \\
\hline & Jumlah & 21,65 & 22,46 \\
\hline & Rata-rata & 3,62 & 3,74 \\
\hline & Kategori & B & SB \\
\hline
\end{tabular}

Berikut adalah gambaran kenaikan rata-rata aktivitas belajar mahasiswa pada setiap siklus yang ditunjukkan pada grafik dibawah ini.

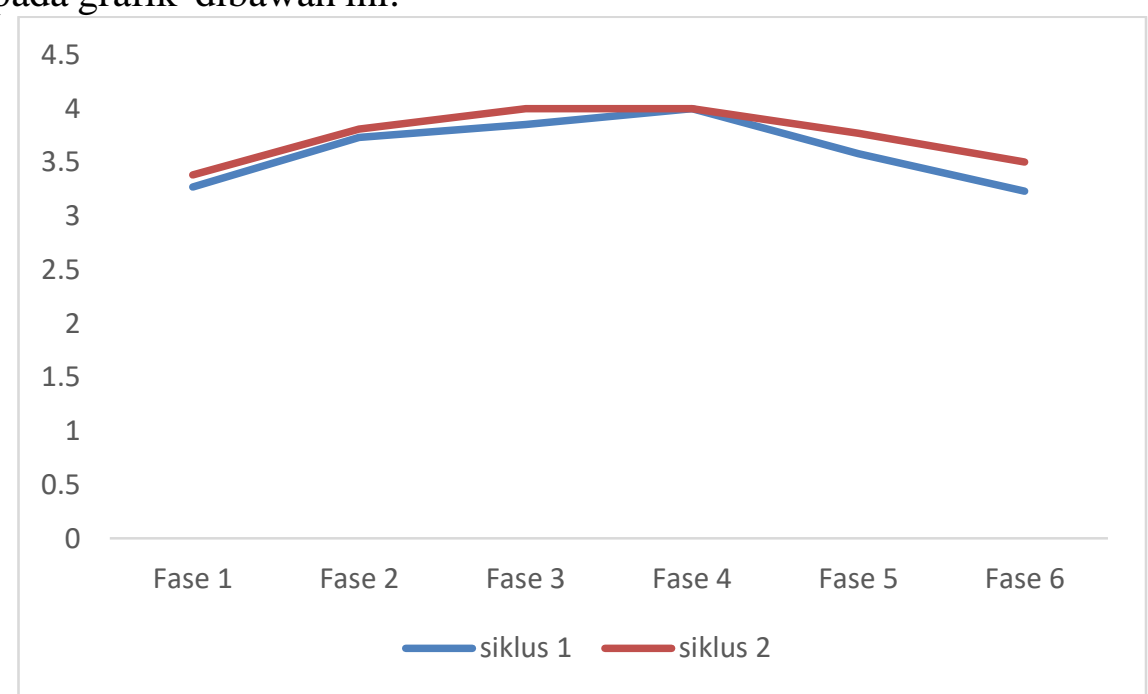

Gambar 1. Grafik Kenaikan Aktivitas Mahasiswa pada setiap siklus

Aktivitas mahasiswa setiap siklusnya mengalami peningkatan, yakni siklus I sebesar 3,62, kemudian pada siklus II meningkat menjadi 3,76. Terlihat bahwa kegiatan belajar dengan menerapkan PjBL dapat meningkatkan aktivitas belajar mahasiswa, sehingga diharapkan juga dapat meningkatkan hasil belajar mahasiswa.

\subsection{Literasi Sains}

Literasi sains bersifat multi dimensional dalam pengukurannya meliputi konten sains, proses sains dan konteks sains (11). Konten sains merujuk pada konsep kunci sains yang diperlukan untuk memahami Listrik Statis dan Listrik Dinamis dalam kehdupan sehari-hari. Proses sains mengkaji kemampuan untuk menggunakan pengetahuan dan pemahaman ilmiah. Dalam penilaian literasi sains tiga aspek proses sains yang ditetapkan mengacu pada PISA (Program for International 
Student Assessment) yaitu mengidentifikasi pertanyaan ilmiah, menjelaskan fenomena secara ilmiah, dan menggunakan bukti ilmiah. Konteks literasi sains mencakup bidang aplikasi sains dalam kehidupan (4) yang dalam hal ini meliputi Listrik Statis dan Listrik Dinamis dalam kehdupan sehari-hari.

Literasi sains menurut PISA (2010) adalah kemampuan menggunakan pengetahuan ilmiah, mengidentifikasi pertanyaan dan menggambarkan bukti-bukti yang berdasarkan kesimpulan untuk dapat memahami dan membantu pembuatan kesimpulan tentang alam serta perubahan terhadap alam tersebut akibat aktivitas manusia. Literasi sains merupakan tujuan yang ingin dicapai oleh mata pelajaran yang berumpun pada sains, yang salah satunya adalah biologi. Standar kompetensi lulusan pada kelompok mata pelajaran IPA (sains) kurikulum 2006 menyebutkan bahwa sains berkaitan dengan cara mencari tahu tentang alam secara sistematis, sehingga sains bukan hanya penguasaan kumpulan pengetahuan yang berupa fakta, konsepkonsep, atau prinsip-prinsip saja tetapi juga merupakan suatu proses penemuan (12). Hasil penelitian literasi sains mahasiswa disajikan pada tabel 3 dan Gambar 2.

Tabel 3. Literasi sains mahasiswa

\begin{tabular}{llrrr}
\hline No & \multicolumn{1}{c}{ Materi } & Konten & Proses & Konteks \\
\hline 1. & Listrik Statis & 70,00 & 75,77 & 66,54 \\
2. & Listrik Dinamis & 73,08 & 79,81 & 69,23 \\
& Rata-rata & 71,54 & 77,79 & 67,88 \\
& Standar deviasi & 4,22 & 3,86 & 3,23 \\
\hline
\end{tabular}

Berikut adalah gambaran kenaikan rata-rata aktivitas belajar mahasiswa pada setiap siklus yang ditunjukkan pada grafik dibawah ini.

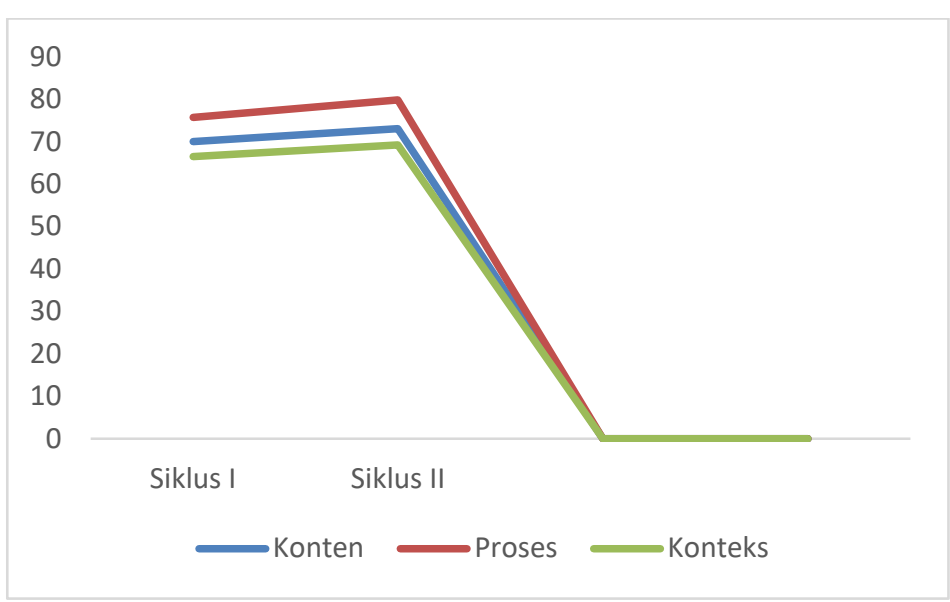

Gambar 2. Grafik Literasi Mahasiswa pada setiap aspek

Dari Tabel 3 dapat terlihat adanya peningkatan literasi sains mahasiswa, siklus II aspek konten sebesar 73,08 lebih baik dari pada siklus I sebesar 70,0 dan aspek proses sebesar 79,81 lebih baik dari pada siklus I sebesar 75,77 serta aspek konteks sebesar 69,23 lebih baik dari pada siklus I sebesar 66,54. Hal ini terjadi karena siklus II mendapatkan pembelajaran PjBL yang merupakan perbaikan hasil refleksi siklus I.

1. Aspek konten sains

Hasil penelitian litrasi sains mahasiswa berdasarkan tabel 3 menunjukkan rata-rata kemampuan literasi sains siswa pada aspek konten sebesar 71,54 atau dalam kategori baik. Konten sains merujuk pada konsep-konsep pokok yang diperlukan untuk memahami Listrik Statis dan Listrik Dinamis dalam kehidupan sehari-hari. Dalam kaitan ini, penelitian ini tidak secara khusus membatasi cakupan konten sains hanya pada pengetahuan yang menjadi materi kurikulum sains SMP kelas 3 saja, namun termasuk pula pengetahuan yang dapat diperoleh melalui sumber-sumber informasi lain. Merujuk pada PISA dalam menentukan kriteria pemilihan konten sains adalah: (a) Relevan dengan situasi kehidupan nyata; (b) Merupakan pengetahuan penting sehingga 
penggunaanya berjangka panjang; (c) Sesuai untuk tingkat perkembangan peserta didik/mahasiswa. Berdasarkan kriteria konten tersebut, maka dalam konten sains dipilih pengetahuan yang diperlukan untuk memahami dan memaknai pengalaman dalam konteks personal, sosial, dan global meliputi bidang-bidang Listrik Statis dan Listrik Dinamis dengan merujuk pada kriteria tersebut.

Hasil penelitian menunjukkan kemampuan literasi sains mahasiswa dalam aspek konten sains dalam kategori baik. Meskipun penguasaan konsep mahasiswa tentang pembelajaran Listrik Statis dan Listrik Dinamis telah tergolong baik, sejalan dengan pembelajaran IPA yang menekankan pada pengusaan aspek konten, namun kenyataanya penguasaan konsep mahasiswa tentang IPA masih miskonsepsi untuk beberapa konsep. Adanya tuntutan terselesaikannya materi bahan ajar oleh dosen sesuai target kurikulum memaksa mahasiswa harus menerima konsep-konsep IPA yang mungkin belum sepenuhnya dipahami. Hal ini menjadikan beberapa konsep-konsep IPA dipahami secara miskonsepsi atau hanya sekedar dihafalkan yang pada akhirnya konsep tersebut mudah dilupakan (12).

\section{Aspek proses sains}

Hasil penelitian literasi sains mahasiswa berdasarkan tabel 3 mennjukkan rata-rata kemampuan literasi sains siswa pada aspek proses sebesar 77,79 adalah dalam kategori baik. Proses sains merujuk pada kemampuan mahasiswa memahami prosedur sains. Dalam hal ini proses kognitif yang terlibat dalam proses sains antara lain penalaran induktif/deduktif, berpikir kritis, mengkonstruksi ekplanasi berdasarkan data. Kemampuan memecahkan masalah, mengidentifikasi dan menginterpretasi serta menerangkan kesimpulan. Termasuk di dalamnya mengenal jenis pertanyaan yang dapat dan tidak dapat dijawab oleh sains, mengenai bukti apa yang diperlukan dalam suatu penyelidikan sains, serta mengenai kesimpulan sesuai dengan bukti yang tersedia (12).

Kemampuan literasi sains mahasiswa dalam aspek proses sains dalam kategori baik. Berdasarkan hasil pengamatan di kelas, proses pembelajaran IPA berlangsung tidak sekedar transfer pengetahuan dari dosen kepada mahasiswa yang dilakukan secara verbal, tetapi juga menekankan pada proses, sehingga mahasiswa memahami konsep-konsep IPA yidak hanya sebagai hafalan.

\section{Aspek konteks sains}

Hasil penelitian literasi sains mahasiswa berdasarkan tabel 3 menunjukkan rata-rata kemampuan literasi sains siswa pada aspek konteks hanya sebesar 67,88 atau dalam kategori rendah. Jika dianalisis, pembelajaran IPA khususnya di kelas 5A Program Studi Pendidikan IPA masih dilakukan secara parsial (terpisah) atau belum terpadu, akibatnya konsep IPA yang diterima oleh mahasiswa juga terpisah. Kecenderungan dosen untuk memberikan materi masih kurang mengaitkannya dengan kehidupan nyata menyebabkan mahasiswa kesulitan mengaitkan pengetahuan yang telah didapatkan dengan situasi kehidupan nyata. Hal ini terlihat dari jawabanjawaban mahasiswa yang masih sangat teoritik sesuai dengan konsep materi yang diajarkan di kelas dan belum mampu mengaplikasikan konsep materi untuk memecahkan masalah-masalah sains yang dijumpai di dalam soal. Hal ini sesuai dengan hasil penelitian yang mengungkapkan bahwa rendahnya literasi sains siswa tersebut diduga karena belum mengaitkan konsep sains dengan kehidupan sehari-hari (4).

Berdasarkan data hasil penelitian, saat ini mahasiswa yang menjadi subyek penelitian hanya memiliki kemampuan mengingat pengetahuan ilmiah berdasarkan fakta sederhana. Proses pembelajaran IPA lebih sering menekankan pada abstract conceptualization dan kurang mengembangkan active experimentation serta rendahnya budaya membaca. Pembelajaran sains cenderung menempatkan materi subyek terlebih dahulu kemudian sedikit aplikasinya. Padahal penerapan prinsip-prinsip sains harus berjalan seimbang sehingga dapat digunakan untuk memecahkan masalah atau mengambil keputusan yang berkenaan dengan masalah sehari-hari (12).

\section{KESIMPULAN DAN SARAN \\ 4.1 Kesimpulan}

Berdasarkan hasil penelitian dan pembahasan diperoleh simpulan sebagai berikut:

Perangkat pembelajaran IPA-3 dengan Pembelajaran Berbasis Project (Project Based Learning) yang valid pada materi Listrik Statis dan Listrik Dinamis dalam Kehidupan Sehari-hari. (2) Ada 
peningkatan aktivitas belajar mahasiswa dengan penerapan Pembelajaran Berbasis Project (Project Based Learning) pada mata kuliah IPA-3 di Program Studi Pendidikan IPA FKIP Universitas Bengkulu. (3) Ada peningkatan Literasi Sains mahasiswa dengan Pembelajaran Berbasis Proyek (Project Based Learning) pada mata kuliah IPA-3 di Program Studi Pendidikan IPA FKIP Universitas Bengkulu.

\subsection{Saran}

Berdasarkan hasil penelitian dan simpulan di atas, ada beberapa saran penerapan pembelajaran berbasis proyek yaitu : (1) Perlunya dikembangkan perangkat pembelajaran yang menunjang pelaksanan literasi sains dalam pembelajaran IPA. (2) Perlunya peningkatan dan pembiasaan budaya membaca/literasi di kalangan mahasiswa calon guru IPA di sekolah.

\section{DAFTAR PUSTAKA}

1. Mawardini A, Permanasari A, Sanjaya Y. PROFIL LITERASI SAINS SISWA SMP PADA PEMBELAJARAN IPA TERPADU TEMA PENCEMARAN LINGKUNGAN. In: Prosiding Seminar Nasional Fisika (E-Journal) SNF2015. Jakarta: Universitas Negeri Jakarta; 2015. p. 49-56.

2. Pratiwi SN, Cari C, Aminah NS. Pembelajaran IPA Abad 21 dengan Literasi Sains Siswa. J Mater dan Pembelajaran Fis. 2019;9(1):34-42.

3. OECD. PISA 2012 Assessment and analytical Framework: mathematics, reading, science, problemsolving, and financial literacy [Internet]. 2013 [cited 2013 Mar 4]. p. 1. Available from: http://www.keepeek.com/Digital-Asset-framework_9789264190511-en

4. NADHIFATUZZAHRO D, SETIAWAN B, SUDIBYO E. Kemampuan Literasi Sains Siswa Kelas VII-B SMP Negeri 1 Sumobito Melalui Pembuatan Jamu Tradisional. In: SEMINAR NASIONAL FISIKA DAN PEMBELAJARANNYA 2015. Malang: Universitas Negeri Malang; 2015. p. 21-7.

5. Latip A. Pentingnya Literasi Sains untuk Generasi Zaman Now [Internet]. Kompasiana. 2017 [cited 2020 Mar 31]. p. $1 . \quad$ Available from: https://www.kompasiana.com/altip/5a3c8824caf7db3b145228f3/pentingnya-literasi-sainsuntuk-generasi-zaman-now?page=all

6. Kebudayaan KP dan. Modul Penyusunan Soal Keterampilan Berpikir Tingkat Tinggi. Jakarta: Direktorat Pembinaan Sekolah Menengah Atas; 2019. p. 1-2.

7. Suharto. Model - Model Pembelajaran IPA dan Implementasinya. Jakarta: Nurul Atma Vita; 2016.

8. Trianto. Panduan Lengkap Penelitian Tindakan Kelas, Teori dan Praktik; cetakan ketiga. Jakarta: Prestasi Pustaka; 2012.

9. Arikunto S. Prosedur Penelitian Suatu Pendekatan Praktik. Jakarta: Rineka Cipta;

10. Widayanti, Yuberti, Irwandani, Hamid A. Pengembangan Lembar Kerja Praktikum Percobaan Melde Berbasis Project Based Learning. J Pendidik Sains Indones. 2018;06(01):24-31.

11. Mahmud AA, Prasetyo JD. Penguatan pendidikan karakter melalui literasi sains dalam pembelajaran ipa sd. In: Prosiding Seminar Nasional Pendidikan Dasar. 2020. p. 240-9.

12. Nofiana M, Julianto T. PROFIL KEMAMPUAN LITERASI SAINS SISWA SMP DI KOTA PURWOKERTO DITINJAU DARI ASPEK KONTEN, PROSES, dan KONTEKS SAINS. J Sains Sos dan Hum. 2017;(ISeptember):77-84. 